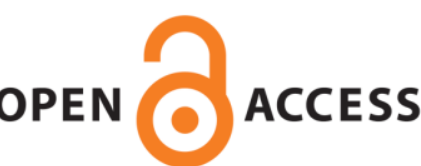

UWS Academic Portal

\title{
What parents in Scotland say about their primary aged children learning about the Holocaust
}

Cowan, Paula; Jones, Tara

Published in:

Educational Review

DOI:

$10.1080 / 00131911.2019 .1601616$

E-pub ahead of print: 26/04/2019

Document Version

Peer reviewed version

Link to publication on the UWS Academic Portal

Citation for published version (APA):

Cowan, P., \& Jones, T. (2019). What parents in Scotland say about their primary aged children learning about the Holocaust. Educational Review. https://doi.org/10.1080/00131911.2019.1601616

\section{General rights}

Copyright and moral rights for the publications made accessible in the UWS Academic Portal are retained by the authors and/or other copyright owners and it is a condition of accessing publications that users recognise and abide by the legal requirements associated with these rights.

Take down policy

If you believe that this document breaches copyright please contact pure@uws.ac.uk providing details, and we will remove access to the work immediately and investigate your claim. 
This is an Accepted Manuscript of an article published by Taylor \& Francis Group in Educational Review on 26 April 2019, available online: http://

www.tandfonline.com/10.1080/00131911.2019.1601616. 


\title{
What parents in Scotland say about their primary aged children learning about the Holocaust
}

Names and Affiliations: Paula Cowan, Reader in Education, University of the West of Scotland, Tara Jones, Associate Lecturer in Education, University of the West of Scotland

Contact email:

Word Count:

Keywords: paula.cowan@uws.ac.uk

9639 (from Introduction); 9805 with Abstract

Holocaust education, primary, interdisciplinary, parents

\begin{abstract}
This paper provides insight into parental attitudes to their primary aged children learning about the Holocaust. Evidence is based on data from interviews with parents whose children learned about the Holocaust in their last year of primary. Findings show that parents had initial concerns about their children learning about the Holocaust, but that these were effectively addressed by the teacher communicating to parents that lessons and activities suited the curricular requirements and their children's needs. Findings further suggest that learning about the Holocaust in school stimulated discussion in the home. We conclude that Holocaust Education can provide opportunities for intergenerational learning and engagement.
\end{abstract}

Keywords: Holocaust, parents, primary education

\section{Introduction}

In Scotland, the term 'parental engagement' is currently used to refer to parental (and family) engagement in their children's learning in school and everyday life. Parental engagement is one of the six key drivers of Scotland's National Improvement Framework whose aim is to improve the outcomes of all young people in Scotland and reduce the attainment gap (Education Scotland, 2018). This policy document recognises that family learning encourages children and family members to learn together, fostering positive attitudes to lifelong learning. Improving and increasing ways in which parents can engage with teachers is fundamental to this policy.

Research findings amongst teachers in England (Centre for Holocaust Education, 2016) and the US (Harbaugh, 2015) suggest that a significant number of primary teachers are choosing to teach the Holocaust. Further, the Holocaust is mandatory in the primary curriculum in France (Heddebaut, 2017; Cowan and Maitles, 2017), the Netherlands (de Bruijn, 2018, p.132), and Israel (Ziv, Golden and Goldberg, 2015). Cassidy, Brunner and Webster's study of 148 student primary and secondary teachers in Scotland were that respondents viewed that parents may be a barrier to teaching human rights. Reasons given were 'conflict in cultures in the UK' and possible disagreement with some human rights by specific religious groups $(2014$, p. 27). One student in this study who invited a Holocaust survivor to speak to the pupils without seeking parents' permission, stated that no parents complained (ibid). Whether parents would have preferred to have known about this learning experience is unknown, and Cassidy et al., (ibid) conclude from their study that the relationship between parents and teachers in teaching about human rights was unclear (ibid). 
The Holocaust was a defining moment in world history that led to the usage of the term 'genocide' (1944), the UN General Assembly's declaration of genocide as a crime under international law (1946), the UN Universal Declaration of Human Rights (1948), the Convention on the Prevention and Punishment of the Crime and Genocide (1948) and the establishment of the United Nations High Commissioner for Refugees (1950).

The United Nations Resolution on Holocaust Remembrance (60/7) has encouraged member states to develop education programmes to address the lessons of the Holocaust (UNESCO Education, 2014). Its broad range of aims and objectives include prevention of future genocides, broader public awareness of the Holocaust, reduction of antisemitism and racism and increased support for human rights (UNESCO Education, 2014). Holocaust Education therefore comprises historical learning about the Holocaust and contemporary lessons from the Holocaust.

This article explores this relationship further by analysing empirical data from parents on their views of their primary aged children learning about the Holocaust. Data also provides insight into parents' perceived views of their own understanding and knowledge of the Holocaust. This is of particular relevance to teachers in Scotland as one of the challenges to parental involvement at home is parents' lack of knowledge about subject curriculum and teaching methodology (Scottish Government, 2005).

\section{Young Children's Learning About the Holocaust}

The teaching that this research focussed on used two approaches to children's learning; inter-disciplinary learning and narrative pedagogy. It is important to emphasise that in this research, the narrative is factual and not fictional. Using fictional narrative as Holocaust Education, raises issues as this does not necessarily provide accurate historical information. Cowan and Maitles state that inaccurate or mis-information leads to further difficulties in learning from the Holocaust (2017, p.117). Importantly, however, the use of non-fictional narrative about the Holocaust raises additional issues linked to psychological harm since students are asked to identify with, witness or experience the trauma alongside the subject of the narrative (cf. Rak, 2003).

Because narratives are intertwined with and shaped by the self and others; they are at the heart of how we make meaning and are central to how we make sense of who we are and how we relate to the world (Bruner, 1991; Gallagher, 2014; Gilbert, Hipkins and Cooper, 2005; Huber, Caine, Huber and Steeves, 2013). Gilbert et al., (2005) state that narrative can help develop an individual's capacity for imagination such as being able to imagine worlds that might be very different to the one they inhabit. Therefore, not only do stories play an active role in constructing a person's reality they also play an active role in transforming it. Gallagher (2014) adds that narratives help to shape understanding of norms and values and can provide an enriched capacity for understanding and social empathy. However, narratives that focus on trauma and experiences of trauma have the potential to cause psychological harm. Mintz's (2013) discussion of the paradox of suffering in social justice 
education contextualises the problem of psychological harm when teaching the Holocaust to fifth grade pupils in France (ages 10-11), where Holocaust education is mandatory in the primary school. This context is particularly relevant to this research given that its focus is on Holocaust education in the primary school. It is also relevant to the narrative used to support learning in this study which was the story of Hana Brady a young Jewish girl from Czechoslovakia who lived during WW2, who at the age of 13, was murdered at AuschwitzBirkenau. Mintz (2013) explains that in 2008 the French president suggested that the French curriculum be changed and children learn the story of a single French child killed by the Nazis in the Holocaust. However, this created controversy because some believed that asking a "...student to identify with a single dead child would be too emotionally painful" (Mintz 2013, p.216).

Mintz, (2013) concludes, however, like others (cf. Zembylas and McGlynn, 2012; Zembylas, 2015) that for emotional engagement to occur at any level, some degree of suffering, emotional violence or discomfort is not only necessary but also unavoidable if moral transformation is to be possible. But, she goes on to argue, it is important that educators distinguish between pedagogically valuable suffering from that which is not. As Zembylas (2015) states, it is important to ask where the line is drawn. Rak (2003), for instance, argues that it is not necessary to take students to the point of 'crisis' with regard to experiencing the trauma of others and that to do this is ethically unacceptable. Although, what might be the point of 'crisis' for one child may well be different to that of another. Zembylas (2015) points to a pedagogy of discomfort which should allow students to unpack their cherished beliefs and values in a safe place where ethical violence or psychological harm should be minimised. However, whilst ensuring that the classroom is a safe place to discuss sensitive topics, classroom safety does not necessarily ensure that students will not experience stress and discomfort (Zembylas, 2015).

In regard to teaching the Holocaust, to children or adults, the question should not be whether emotionally disturbing material should be introduced, but how much and in what context. In this regard, concern about the approach to teaching the Holocaust is as important as the content. Many researchers and Holocaust educators share the view that the horrors of the Holocaust should not be taught to primary students, (e.g. HET, 2016; Totten, 1999; Woolley, 2010) and it is likely that the anecdotal evidence indicating parental concerns about teaching the Holocaust in primary schools are reflective of these concerns. However, there is a lack of consensus in defining exactly what these 'horrors' are and this leads to tension. Simone Schweber (2008, p. 2076) summarises this tension by stating that a suitable 'preparatory version' (of the Holocaust) for young learners can be misleading while the fuller version is "too complex, too appalling, too impenetrable, too emotionally disturbing".

Here it is important to take into account the emotional wellbeing and resilience of students as well as what is necessary for students to be able to learn the important moral and ethical values required. It is widely accepted that children's emotional development matures gradually (cf. Saarni, 2011) and thus children are not, therefore, able to cope with or even 
process emotionally disturbing material to the same level or in the same way as adults. Thus, what would be appropriate for adults would not be appropriate levels of emotional disturbance for children and, the younger a child is, the less emotionally disturbing the content should be. In this respect it is as important that teachers know and understand the capacities, capabilities and experiences of the children in their classrooms as well as their own particular stories or narratives (see for example Goodson, 2013 for an extended discussion) and take this into account when considering new narratives to present to children.

In an attempt to offer guidance to primary teachers, Cowan and Maitles (2017, pp. 110-114) identify the narratives of Anne Frank, the SS St. Louis, the Kindertransport, and the Rescue of the Danish Jews as suitable themes for students aged 10-12 years. Further, Cowan and Maitles (ibid) identify the children's non-fictional text Hana's Suitcase (Levine, 2003) as an appropriate resource for P7 pupils (11-12 years). This text is narrated through the lens of the curator of the Tokyo Holocaust Centre and a primary class she is working with, as they research what happened to Hana Brady who lived during the Holocaust. This text is sensitive and mindful of the capabilities of primary age children, using appropriate language and context and providing sufficient detail for children to understand the main facts without terrifying details. Containing photographs, drawings and archival documents, this book 'takes' primary aged pupils into the Theresienstadt ghetto and camp, and can be used as a vehicle for incorporating music into Holocaust education and learning about the musical and artistic activities at this camp.

Some educators consider it inappropriate to engage primary aged readers with the activities of a concentration camp thereby telling a more 'fuller' than 'preparatory' version of the Holocaust, and places a greater responsibility on teachers who consistently strive for good relationships with parents. This book is one of many teaching resources that Scottish primary teacher use to teach the Holocaust. When Dundee City Council hosted the National (Scottish) Holocaust Memorial Day event in 2012, it distributed copies of this book in each of its primary schools. This book was also used by one of the primary schools in Cowan and Maitles longitudinal study (2005) on the value of teaching the Holocaust in the primary school. It is possible that parents' concerns are linked to the above educators' views. Adeline Salmon, co-ordinator of educational workshops at the Shoah Memorial, Paris, recognises the importance of preparing parents of children aged 9 to 12 years, for their children's visit to the Memorial. Salmon contacts parents who have strong reservations about their child's participation and tries to reassure them by explaining that no violent images will be shown. One of the responsibilities of the class teacher, Salmon reports, is to ensure that parents have clear expectations of this visit (UNESCO, 2011).

In their article on teachers who teach the Holocaust in the USA, Deutsch, Perkis, and GranotBein write that the growing body of Holocaust educational research include few studies that consider the role of teachers (2018, p. 87). Similarly, parents' views and input are not included in Ziv, Golden and Goldberg's (2015) study of the educational and ethical perspectives in teaching the Holocaust in Israel to pre-school children. Neither are they included in the Memorial de la Shoah guidelines for teaching children between 8-12 years 
(Memorial de la Shoah online, n.d.). We assert that this body of research does not consider parents, and our attempt in this present paper to explore parents' views of their primary aged children learning about the Holocaust, has implications for teaching the Holocaust and controversial and sensitive issues to young learners.

\section{Teaching the Holocaust in Scotland}

One of the four countries that comprise the United Kingdom, Scotland has its own Parliament with the responsibility for a wide range of devolved issues such as education. This means that all educational matters are discussed and decided by the Scottish Parliament. Because the Holocaust is not mandatory in either the primary or secondary curriculum, school-based Holocaust education in Scotland relies on Head Teachers, and/or Directors of Education who are committed to the Holocaust being taught in their schools, and to teachers, like the Class Teacher (CT) in this study, who choose to include Holocaust education in their programme of work.

Interdisciplinary Learning (IDL) is an important element of the Scottish 3-18 curriculum, Curriculum for Excellence ( $\mathrm{CFE}$ ), and is a popular way of teaching the curricular area of Social Studies, which is a combination of History, Geography, Modern Studies and elements of Business Studies (Robertson, Hepburn, McLauchlan and Walker, 2017). One of the criticisms of IDL is the lack of consensus by teachers as to what it means. One interpretation of this is that it is like cross-curricular learning involving the use of a number of disciplines to develop an understanding of a theme or topic; another is that it is the "understanding and appreciating connections and differences between subjects, and of how this influences ways of perceiving and engaging with learning tasks" Thorburn (2017, p. 246). 'Hana's Suitcase' lends itself very well to learning about the Holocaust through IDL.

Cassidy et al., (2014, p.22) point out that in CfE, Human Rights Education should be taught through subjects such as 'Health and Wellbeing, Social Subjects, and Religious and Moral Education' and that its 'overarching banner' is Citizenship Education. IDL is better suited for primary teachers than secondary teachers (Humes, 2013, p.88) and this is supported by findings from Scottish schools that demonstrate teachers in the later stages of primary schools are more receptive to this approach than their secondary peers (Menter and Hulme, 2013). This can be further explained by the flexible primary timetable and reliance, in the main, on one teacher to deliver the whole of the curriculum, that places less organisational demands to teach IDL than in the secondary (Robinson, 1989; Maitles and Cowan, 1999). This learning approach is not new; it has been infused in the Reggio Emilia philosophy to learning in early years education (e.g. Kinney and Wharten, 2007; Edwards, Gandini and Forman, 2011), and primary teachers have for many years used topics as vehicles to promote children's understanding of a wide range of curricular areas.

Cowan and Maitles' longitudinal study of young children in Scotland, found gains in children's understanding of racism, human rights and refugees (2005). Further, Cowan and Maitles (2010) claim that Scotland's curriculum, and the introduction of Holocaust Memorial Day have contributed to the growth of Holocaust Education in Scotland. The emphasis in 
the Scottish curriculum on citizenship has provided additional impetus for school-based Holocaust education as one of the purposes of this curriculum is to help young people become responsible citizens (Scottish Executive, 2004; Education Scotland, n.d.a). Jerome Bruner's statement that "any subject can be taught in some intellectually honest form to any child at any stage of development" $(1977$, p.33), supports teaching complex material, such as the history of the Holocaust, to young learners. Further, Bruner views the curriculum as a spiral where learning begins with content that meets the learner's abilities, and that this learning is reinforced and developed until the learner has mastered the content (Bruner, 1996). In the context of Holocaust education, primary pupils' first learning of the Holocaust can be built on in secondary, and on leaving school, this learning will, regardless of age or developmental level, be stored in pupils' long-term memory.

More recent initiatives have been made by the largest education union in Scotland, the Educational Institute of Scotland (EIS), who in 2017 passed a motion that Holocaust Education be included in the Scottish curriculum, (SEJ, 2017, p.12). The publication that followed their (Scottish) national audit on Holocaust Education in local authorities and initial teacher education providers, reported examples of parental engagement in this area and recommended that coverage of Holocaust education be included in Initial Teacher Education to support teachers (EIS, 2018). Also in 2017, the University of the West of Scotland, in partnership with the Holocaust Educational Trust, launched Vision Schools Scotland, an accreditation programme for primary and secondary schools in Scotland that demonstrate commitment and good practice in Holocaust education (GTCS, 2017, p.32).

\section{Methodology}

The research was a case study set within an Interpretive Phenomenological Analysis (IPA) approach to data collection and analysis. IPA is a qualitative approach increasingly popular in psychology, influenced by three main theoretical orientations: phenomenology, hermeneutics and ideography (Pietkiewicz and Smith, 2012). Phenomenology is concerned with the meanings people make of their social and personal world whilst hermeneutics recognises the interpretive nature of understanding (Carpenter, 2009; Pietkiewicz and Smith, 2012; Smith and Osborn, 2007). Ideography is interested in the single case and the unique and individual perspectives of participants (Pietkiewicz and Smith, 2012). Thus, because this research focussed on a single case example of one school and sought to understand the unique and individual perspectives of parents, IPA was an appropriate tool.

Case studies are a method often used in IPA and are useful because they describe something intrinsically interesting (Smith, Flowers \& Larkin, 2010). Case studies are a powerful tool because they can highlight anomalies, create challenge to existing knowledge and understanding and provide insights into individual perceptions and experiences (Gillham, 2000). Case study research often involves collecting and interpreting narratives (Woodside, 2016) and it has been suggested that the best way to present a case is to report it as a narrative (Gillham, 2000). This is because people naturally think narratively and a large amount of what we retrieve from memory is episodic (Woodside, 2016). More importantly, 
case studies are useful because they can draw attention to 'flaws in existing theoretical claims' and provide 'a means of troubling our assumptions, preconceptions and theories' (Smith, Flowers \& Larkin, 2010, p.30).

Some approaches within the IPA tradition consider that a case can consist of one participant, collecting data from them only once (cf. Smith, Flowers \& Larkin, 2010). Interviewing in this respect can be considered a good method of data collection due to the richness of the communication, the ability to probe and clarify and check meaning (cf. Gillham, 2000). Of course, a problem with case studies is that they are idiographic and not representative of the general population so data cannot be as readily generalizable as, perhaps, larger data sets. Nevertheless, the purpose of a case study is not to generalise findings but to probe a theory and it is important to note that any study can be idiosyncratic in relation to the limits of its sample population, data collection and analysis so this is not unique to case studies (Woodside, 2016).

The school case study context for the research is a relatively affluent area in Renfrewshire, Scotland with 32 pupils in this class. The class teacher (CT) chose to integrate the Holocaust into the class topic of World War Two; to the class teacher's knowledge, although this topic had been frequently taught to primary 7 pupils in this school, the Holocaust had not been taught before. Hana's Suitcase (Levine, 2003), was a core text in this topic. From the data available, it is unclear as to which interpretation of IDL best describes the practices of the CT in this study. However, the CT taught the Holocaust through Social Studies, Literacy and English, and Expressive Arts through developing skills and knowledge in Music and Art (Duffy and Cowan, 2018).

Prior to teaching the World War Two and the Holocaust, the CT wrote a letter to parents outlining this topic, explaining that their children would be engaging in a novel study on 'Hana's Suitcase', which told of the experiences of a young Jewish girl who was taken to Theresienstadt concentration camp. This approach, is in accordance with the Scottish Schools Parental Involvement Act $(2006$, p.5) which advises that the better the information that schools provide to parents, the more parents can support their children's learning and the school. The letter requested parents monitor their child's personal research on the Holocaust to avoid exposing them to upsetting and disturbing images. The CT invited parents to contact him with any questions. The CT reported that no parent contacted him. At the end of the topic, parents were invited to the school for an Open Day, to see their children's work, and watch their children's Assembly presentation that focused on the Holocaust.

Data was collected from semi-structured interviews and were conducted by the same interviewer. The benefits of semi- structured interviews are well documented (e.g. Bell, 2014; Denscombe, 2003; Drever, 2003; Schostak, 2005; Whiting, 2008). Such interviews can be used to "to elicit information on people's perceptions, attitudes and meanings" (Menter, Elliot, Hulme, Lewin and Louden, 2011, p. 126). Further Sorrell and Redmond (1995) and Whiting (2008) state that semi-structured interviews help the interviewer to elicit some extra information, depending on the interviewee's replies, important for the purposes of the given research. Semi-structured interviews are one of the best ways of collecting data for 
IPA studies given their flexibility for modification and further probing in light of participant responses (Smith and Osborn, 2007). So, whilst the researcher did have some set guiding questions it was possible to probe and explore interesting and important areas of participant narratives. Interviews were conducted in pairs to facilitate discussion, although availability led to one parent being individually interviewed and were approximately 45 minutes in length. Whilst IPA interviews are usually about hour long and are often conducted one-to-one other approaches are acceptable (Pietkiewicz and Smith, 2012). There was, in this research, a recognition that time was an issue for parents and interviews were conducted at the school. Interviews were recorded using a dictaphone in MP3 format and were transcribed once each interview had been completed.

Sample sizes in IPA are usually relatively small in order to gain a full depth and appreciation of participant narratives (Pietkiewicz and Smith, 2012). Thus the number of participants in the study was ample and comprised of seven parents whose children learned about the Holocaust in their last year of primary. This single case example of one school and small sample of parents may be viewed as a limitation of this research since findings may not be generalisable to the broader social context. However, a single case may well be useful with regard to falsification of a theory or perspective (Flyvbjerg, 2006) and in the case of anecdotal evidence that parents are negatively inclined towards Holocaust Education in the primary school may be insightful. Participants were identified by the CT and then approached and recruited by the researcher. Participants were identified as parents who frequently communicated with and contributed to the school. Parents' age range was 30-45 years and participants comprised one male and six females. Participants are identified using a number in order to retain anonymity. The research was subject to strict ethical guidelines and ethical approval was sought and granted by the University Ethics Committee, the school's authority, school and parent participants.

Analysis did not begin until each interview had been conducted and was carried out using NVivo 8 software. Analysis using IPA is not prescriptive, although does involve immersion in the data and themes generated by exploring key meanings through interpretation of single cases first before comparing across cases (Smith and Osborn, 2007). Therefore, analysis firstly sought to separate, as much as possible, each participant's narrative into an individual narrative. This enabled the researcher to explore individual experiences and perceptions more easily as well as become immersed in the data through repeated listening and reading (cf. Pietkiewicz and Smith, 2012). In order to attempt to understand each participant from their own perspective initial coding saw each interviewee's answers coded individually by question using 'in vivo' codes. Coding by question enabled understanding to be linked to specific topics and enable comparison more easily across participants as well as themes developed around specific points.

\section{Findings}

All participants stated that they considered the Holocaust to be a suitable topic for P7 pupils. However, participants made it clear that this depended largely on how it was taught 
and most thought that learning about the Holocaust might not be appropriate for children younger than this age. They also emphasised that their view was influenced by the diverse interdisciplinary experiences that were skilfully presented and taught by their Class Teacher. Five participants stated that they had initial concerns about their children learning about the Holocaust as they had thought that this study would focus on the horrors of the Holocaust. Their first thoughts were that resources such as, 'horrific photos and stories' might be used in the classroom.

when we got the letter to say that $L$ was going to be doing, doing the Holocaust I did take a kind of (breathes in and makes face) oh, you know like 'oh god' you know, like my goodness, how are they going to put that across...will she be told any, you know 'horrific stories' will they see lots of images that will stick in her mind

(Parent 2).

I always think of those horrific photos you see of the piles of bones and people's belongings and things

(Parent 7).

Parents' concerns were influenced by a view that their children could be vulnerable to becoming traumatized by difficult and sensitive topics. They considered the Holocaust to be such a topic.

I think for some children if they are very (pause) sensitive, sensitive children they would probably struggle with some of that stuff and I mean, I can picture images in my head now from something, whether it's been from a book or a movie but, you know, it's just, it's horrible, it doesn't really leave you and I think (pause), I'm more equipped as an adult to deal with that and, you know, for children aged 12 or so they were when they were learning this, it needs to be managed quite carefully because that could really traumatise some of them.

(Parent 1).

Despite these initial concerns, parents said that because the topic had been outlined to them beforehand by the class teacher, and because they trusted the class teacher, they had no continued concerns. The comment by Parent 6 is indicative of the sentiments of the rest of the participants

We did get a letter, I'm sure $\mathrm{Mr} X$ (teacher) had written a really sensible letter like, this is going to be aimed at their age group, and so, I felt confident that he wouldn't be showing things that I didn't want them to see.

(Parent 6).

In addition, prompted by their child studying Hana's Suitcase at school four participants read this book, either on their own or with their child. This enabled participants to reflect that this book was appropriate for their child. As the children had talked about what they had learned at class at home, their parents, indirectly, had some knowledge of what their children were learning about. Parents' involvement at the Open Day provided parents with more direct knowledge of their children's learning of the Holocaust, as they viewed their children's artwork and writing on the wall and heard the musical presentation at the 
Assembly. Participants commented on the content and teaching of the Holocaust related to the information presented to their children and the interdisciplinary links. Participants said they felt that the Holocaust had been presented in a way that focussed on the facts and was well linked to the curriculum. One participant drew attention to links between music and the Holocaust, another to the links between religion and the Holocaust, and another to the links between history, the world today, and the Holocaust:

There was a piece of music or something like that as well about that camp. They were all learning to play a piece of music or something as well

(Parent 1).

And we had interesting conversations about religion. And religious people...And all of that, you know. 'How come' you know 'religious people because they' you know, talked about sort of the whole the idea that the Jewish community were targeted by people who went to church

(Parent 5).

I was pleased that he was doing that as part of the topic cause I think that is a, obviously really relevant to World War Two...and there's other issues even relevant to things going on today so I was pleased that he covered that about, just general prejudice and treating people, you know, fairly and then the unfairness of the situation so I think it was good that all those things came out

(Parent 7).

Overall, participants reported that their children had had a positive experience learning about the Holocaust. They drew attention to how much their children had engaged with the topic which was linked both to the story of Hana as well as the interdisciplinary approach taken by the teacher. Parents had nothing but praise for the teacher and the comment below is indicative of the view of all of the participants.

I think the way it was approached and the way it was taught, great, I think it was very positive...L was certainly very interested in it and she's retained a lot of information so yeah, I think that speaks volumes... now got an understanding of what the Holocaust was and, but not in a way that's upsetting to her (parent's daughter)

(Parent 2).

One additional finding was that participants had learned something about the Holocaust, through their children's learning. Parent 4 indicated that she had learned a lot through her child's learning of the Holocaust and that this had had a big impact on her:

I didn't know a lot about it myself so it was good for me because then I started googling and reading up on a lot of stuff and going 'oh, she's going to ask me 10 million questions, I'm going to have to be google this and find out about it'. So it was good for me as well because I actually learned an awful lot about it myself of, even wee things you didn't realise had happened and stuff... Yeah, I did learn a lot of different aspects of it

(Parent 4). 
The other participants perceived that they had not learned anything, about the Holocaust, yet they reported that their children's study of the Holocaust had prompted lots of conversation and discussion at home, and that this had led to their reflections of the Holocaust.

I think just discussing it with her and just me giving her bits of information and then she was talking about it refreshed my memory (of the Holocaust) a little bit

(Parent 2).

We talked about how easy it is to demonize the whole German people and say 'well they all just stood back and let it happen'. But then, you know when you talk about it and you think, do you know... How, how would you, what would you do if there were a whole troop of soldiers at your door and it's either you or the, you know it's, it's easy to judge from a distance as well.

(Parent 5).

This suggests that participants had learned about a child's perspective of the Holocaust. Participants talked about perceiving the Holocaust through fresh eyes; the eyes of a child and of a parent, and empathising with how it must have felt to have been a Jewish child or parent during the Nazi regime. For the following three participants, the story of Hana, and the Assembly were important in reminding them that children were murdered in the Holocaust, and how it must have felt to be a parent. This engendered a deeper connection in her and the Holocaust.

I learned more of just say, well kind of what happened to families more....and it was like, say with her book, like, it was erm, a children's point of view and it was funny, in a way you didn't think of a children's point of view, you just thought of the parent's point of view, of an adult, because a lot of times in documentaries and that you only kind of see the adults...And the documentaries and stuff in the concentration camps you didn't really think of it it's children and to think of it from a child's (perspective)...

(Parent 4).

...For me it was good to see it from a parent's point of view and see how that, how it impacts on a child....., but I think that, as a parent it's being able to talk about it with it with your child and answer your child's questions from their point of view rather than from, as opposed to as a teacher in a classroom situation... But actually the emotional connection that you have with your child when you talk because there is that sense of sitting down with them and talking with, how it must have felt for her family, for her and, you know, what, these camps would have been like and mums and dads want to protect their children and the powerlessness of it all

(Parent 5).

And having those children sitting there, behind, they're like behind, so you had the projector and kids are all behind there all just sitting 
cross legged with their glockenspiels in time..... You can't help but

look at them, think, you know, those kids (were) like ours

(Parent 6).

\section{Discussion}

Some concern has been raised in the academic literature about what is appropriate to teach younger children about the Holocaust (e.g. Becher, 2009; Eckmann and Stevick, 2017, pp. 293-295; Peaceman, 2003; Schweber, 2008; Totten, 1999). Given that pupils in this study learned about a child's experiences at Theresienstadt concentration camp, in Schweber's terms 'the fuller version' of the Holocaust (2008), it would not have been surprising had parents conveyed serious and consistent concerns about this topic. Yet participants explained that their initial concerns were short lived as a number of factors helped to alleviate their concerns.

The first factor was the trust that parents placed on the class teacher's competence and commitment to meeting the needs of their children. Data demonstrated that parents viewed this teacher to be exemplary and that he provided the children with additional grounding and emotional security. The development of mutual trust and respect between teachers and parents is emphasised in Scottish education policy (Education Scotland n.d.b). Such trust may not exist in every school, and parents, may be justified in not having this level of trust in their class teacher. In this situation, while it is not clear what redress parents may have, good communication with parents involving the teacher listening to parents is important.

Participant trust in the class teacher in this study was developed through parents' discussions at home with their children. These demonstrated their children's engagement and interest in the interdisciplinary activities and the book, and their comments overwhelmingly centred on the narrative of Hana's Suitcase. This is particularly interesting given that there had been some concern in the academic literature that the narrative of one young girl who did not survive the Holocaust would be too harrowing (see Mintz, 2013). In contrast, in this study, participants commented enthusiastically about how the narrative of Hana Brady had not only stimulated their children's interest but had helped them to engage with the lessons of the Holocaust and encouraged them to share their learning with their parents.

Schweber's findings (2008) that one third grade pupil (8-9 years) became depressed and required to visit the school counsellor after learning about the Holocaust, demonstrates the complexity of teacher trust, as the class teacher in this study was highly respected, experienced and had previously taught the Holocaust, slavery and the genocide of Native Americans. This teacher had included explicit readings on Auschwitz, and information as to how Anne Frank had died, in lessons, i.e. content on the 'horrors' of the Holocaust.

Similarly, teachers with a very limited or inaccurate understanding of the Holocaust and/ or its teaching challenges, whom parents respect may inadvertently or unwittingly take their children on an inappropriate learning journey. Hence parental trust in the teacher may not always be beneficial to children. 
The second factor is the core resource and the adopted teaching approaches. Participants commented that learning through the narrative of a child, of a similar age to their children, had enabled their children to make meaningful connections in different subject areas and see the Holocaust through the eyes of Hana. This provided not only an emotional and empathic connection but also a comparison with their own lives that made sense to them. This combination of narrative and IDL approach that explored culture, music and art, enabled pupils to relate to Hana and thus identify with her experiences in way that enabled them to be angry or indignant about injustice without being traumatized.

Participants indicated that the narrative approach, whilst a highly engaging story of one child's journey, enabled important facts to be presented in such a way as to provide sufficient historical content. This contrasts with Short's (2003) concerns that many pupils in the UK have very little contextual understanding of the Holocaust and may find it difficult to identify with the principal victims and survivors of the Holocaust and thus perhaps not learn the key lessons (ibid). Also, the use of this specific book, with its factual information, photographs, and archival documents presents the Holocaust in a rich and varied way that appealed to pupils, and allowed them to make connections between the different representations, and unpack history. In addition, the narrative style of the story, allowed pupils to identify with the main character (Hana) and her experiences in a concrete way but also enabled pupils to distance themselves, to some extent, from the trauma and so remain emotionally and psychologically safe. This is supported by parents' comments about the story of Hana, that whilst provoking outrage or anger in their children, did not distress them to the extent that they experienced secondary trauma.

The third factor is the class teacher's effective communication with parents prior to and at the end of his teaching the Holocaust. His letter welcoming questions from parents and outlining the topic prior to its teaching, demonstrated a serious commitment to parental involvement and encouraging parent voice. The planned Open Day that demonstrated the class's work on the Holocaust conveyed transparency in the pupils' study of the Holocaust, exposing pupils' responses to the topic.

Findings also raise issues of the teacher's role in this teaching context and draw attention to the need for discussion about children's competencies and whether they are more competent to deal with sensitive and difficult topics than some theories of childhood might previously have believed (cf. John, 2003; Schiller and Einarsdottir, 2009). Of course, this does not suggest that children necessarily have the coping skills or life experience that can equip them to deal with the horrors of the Holocaust in the same way that adults may be able to. Further, it does not suggest that primary teachers should necessarily include content about the camps in their pupils' first lessons of the Holocaust. Rather, it suggests that if children are able to make sense of and relate to sensitive and difficult topics at an appropriate level then it makes sense to prime them earlier in order to provide a level of inoculation against racism and discrimination, as well as instil a sense of what is just in a democratic society. In such situations, teachers need to consider ways in which parents can be formally and informally involved in this. Teachers also need to take into account the distressing and sensitive nature of the content of Holocaust Education and recognise that 
younger children, who have less life experience and less developed coping mechanisms, or children who might be experiencing personal difficulties themselves, do need to be protected from trauma and psychological harm.

Sharing their classroom learning with parents was important in protecting pupils from the potential trauma and psychological discomfort of learning about the Holocaust. It could be argued that this family learning is not a benefit but a necessity since it provided an extra buffer and an opportunity for children to talk about the Holocaust in a safe and nurturing environment (see Zembylas, 2015). This is supported by Judith Vandervelde, an educator at the Jewish Museum, London who stated "Like sex education, Holocaust education has to be supported at home. It depends on the child's maturity, family background and their experiences of death" (Kolirin, 2011, online). However, it could also be argued that the children and families in this study were more resilient than other children. For example, children who do not have anyone they feel able to talk to at home, are disadvantaged and this has implications for teachers and their subsequent Holocaust teaching. It follows that teachers should consider personal circumstances of their children and families.

Parents commented that instead of coming home with nothing to say about school, their children were keen to talk to them about the Holocaust and thus spend quality time with them. Again, it is important to consider the family dynamics here and in this study it would appear that parents and children enjoyed positive family relationships. In addition, most of the parents perceived they had a substantial knowledge and understanding of the Holocaust. In families where parents may not have that knowledge and understanding it is important to consider how parents might be supported to ensure that they are able to support their children appropriately. Participants may well have benefited from recommended reading or suitable websites to develop their understanding of the Holocaust and enrich their discussions with their children at home. It follows that our recommendation is that teachers provide this as well as advice to parents on what is appropriate to discuss and share with their children. In addition, as noted previously, it is necessary to consider what additional support is given to children where family dynamics might be less functional.

Our findings challenge the assumption that school-based Holocaust education is learning that is exclusively for pupils; and the commonly held view that Holocaust learning for primary pupils should never include content on the concentration camps (HET, 2016; Shawn, 1999; Woolley, 2010). In Scotland, P5-7 pupils are required to discuss the importance of people and events from a particular time in the past, and develop an understanding of the forms of discrimination against people in societies and the impact this has on people's lives, in the curricular area of Social Studies (LTS, n.d). We demonstrate that some parents learned about the Holocaust through their children's study of it and that primary children can be 'taken' beyond the gates of the camp as long as it is handled sensitively and accurately and in a way that enables pupils to engage. A narrative pedagogy is one such way. We argue that this approach is justified as it provides a sound context for pupils' understanding of Hana's experience. However, it is important to recognise that while this class teacher was able to teach this in an appropriate way, other class teachers may not. As previously stated, trust in the teacher was a key factor in parents' positive response to the 
topic being taught and alleviating their concerns that their children would not be exposed to inappropriate, harsh images, content on death camps, or find this part of the World War Two topic difficult or traumatic. Thus parents' experiences and perceptions of the teaching of the Holocaust in primary school is very likely to depend on the knowledge, interest, talents and skills of individual class teachers and the relationships that parents have with these teachers.

Parents do have concerns about their primary children's learning about the Holocaust, but these alone are not necessarily a barrier to teaching the Holocaust to primary pupils. Our findings show that one class teacher effectively addressed these concerns. Given the sensitivities and range of content that a study of the Holocaust could include, our recommendation is that primary teachers acknowledge parent concerns to be legitimate, expect parents to be concerned about their children's learning of the Holocaust, and factor this into their programme planning. Further, primary teachers should consider the possibility that some parents will want to find out more about how and what their children are learning of the Holocaust. This has implications for newly qualified primary teachers who are developing their skills in working with parents, and teachers who are less confident in engaging with parents; such teachers would be better to wait until they have the required skills and confidence before teaching the Holocaust.

One of the strengths of this research is that it provides, more broadly, some insight into parental views about the teaching of one sensitive and difficult educational topic. The analysis focussed on an interpretation of themes from individual narratives and compared these across narratives to develop a robust interpretation of parent's shared perspectives. Of course, given the small size and sample of this research it is not possible to generalise the findings across all primary schools. It does, however, provide a starting point for exploring parental views further. The most obvious weakness in this research is the school context. The personal unique skill-set, narrative, and knowledge of the 'exemplary' class teacher in this study make it an impossible study to replicate. However, this does not detract from the lessons learned with regard to the pedagogical approach and the importance of narrative as a tool for teaching.

We can consider how children develop their understanding of abstract or scientific concepts, particularly from a Vygotskyian perspective. In learning to conceptualise abstract ideas or realities that they have no experience of, children need to be able to synthesise their understanding of the abstract through the concrete (cf. Swanson and Williams, 2014). In other words, whilst abstract concepts might be introduced by a more knowledgeable other in a top-down manner it is necessary for children to link these to their own realities and understanding in order to begin the cognitive journey of making sense of them (Vygotsky, 1931/34/1994; Vygotsky, 1934/35/1994; Wells, 1994; Alves, 2014). In consideration of this, it is important that schools develop pedagogies, including narrative pedagogies, that reflect and are inclusive of the personal realities of the children they work with. This has been demonstrated to be important for both children and parents to enable them to engage with the lessons of the Holocaust. In addition, if teachers can work collaboratively with parents this will serve to strengthen and develop a more differentiated and child-focussed approach 
to their classrooms, improve relational skills of the children they teach and draw on a range of potential narratives to support child and family learning. Therefore, further research in this area that involves either a larger number of parents in several primary schools or further systematically sampled case studies would provide further insight into parents' attitudes and their extended learning.

\section{Conclusions}

The following tentative conclusions can be derived from the findings of this research. Holocaust Education, from the perspective of parents, can be appropriate in the primary school depending on the approach taken, the level of communication and strength of relationships between school and home, and the competence of the teacher in being sensitive to the needs of children in his classroom. Further, our findings have demonstrated that teaching the Holocaust can have a positive impact on some parents' understanding of the Holocaust. This is particularly with regard to a relational rather than a purely factual understanding both in terms of the events of the Holocaust and impact on the victims and, in terms of parents' own relationships with their children. We consider this paper to be a useful starting point for further research with parents who are randomly selected from a cross-section of schools across the UK. This would involve parents from different ethnic and cultural groups who may not be supportive of their school, or consider the Holocaust to be an appropriate topic for their primary 7 children. Such research would present a more meaningful understanding of parental views and intergenerational learning about the Holocaust, as well as support schools in developing trusting, collaborative relationships between teachers and parents.

\section{Acknowledgement}

This work was supported by the National Holocaust Centre and Museum, Laxton, England.

\section{References}

Alves, P.F. (2014). Vygotsky and Piaget: Scientific concepts. Psychology in Russia: State of the Art, 7 (3), 24-34.

Becher, A. (2009). Die Zeit des Holocaust in Vorstallungen von Grundschulkindern: Eine empirische Untersuchung im Kontext von Holocaust Education [The Time Period of the Holocaust in the beliefs of primary school children: An empirical study in the context of Holocaust education], Oldenburg: Didaktisches Zentrum.

Bell, J. (2014). Doing Your Research Project: A Guide for First-Time Researchers in Education. 6th ed. Berkshire: Open University.

Bruner, J.S. (1991). The Narrative Construction of Reality, Critical Enquiry, 18, 1-21.

Bruner, J.S. (1977). The Process of Education. New York: Vintage Books. 
Bruner, J.S. (1996). The Culture of Education. London: Harvard University Press.

Carpenter, C. (2009, September). Considering the efficacy of Interpretative Phenomenological Analysis (IPA) as a means to reveal teachers' implicit theories of learning. Paper presented the British Educational Research Association Annual Conference, University of Manchester,

Cassidy, C., Brunner, R. \& Webster, E. (2014). Teaching Human Rights? 'All hell will break loose.' Education, Citizenship and Social Justice, 9(1), 19-33.

Centre for Holocaust Education (2016). What Do Students Know and Understand About the Holocaust? London: UCL.

Cowan, P. \& Maitles, H. (2005). Values and Attitudes - Positive and Negative: A Study of the Impact of Teaching the Holocaust on Citizenship Among Scottish 11-12 Year Olds. Scottish Educational Review, 37(2), 104-113.

Cowan, P. \& Maitles. H. (2010). Policy and Practice of Holocaust Education in Scotland, Prospects 40(2), 257-272.

Cowan, P. \& Maitles, H. (2017). Understanding and Teaching Holocaust Education, London: Sage. de Bruijn, P. (2018). Transcending Moral and Emotional Engagement : The Use of Holocaust Heritage in Primary Education. In C.W. Szenjmann, P. Cowan \& J. Griffiths (Eds.), Holocaust Education in Primary Schools in the Twenty-First Century - Current Practices, Potentials and Ways Forward, (pp.129-144). London: Palgrave Macmillan.

Denscombe.M. (2003). The Good Research Guide for Small Research Projects. Maidenhead: Open University Press.

Deutsch, N., Perkis, N. \& Granot-Bein, Y. (2018). Six Teaching Orientations of Holocaust Educators as Reflections of Teaching Perspectives and Meaning Making Processes, Teaching and Teacher Education, 71, 86-97.

Drever, E. (2003). Using Semi-structured Interviews in Small-scale Research: A Teacher's Guide. Edinburgh: Scottish Council for Research in Education.

Duffy, G. \& Cowan, P. (2018). Poetry, charcoal and a requiem: an interdisciplinary approach to teaching the Holocaust to primary students. In C.W. Szenjmann, P. Cowan \& J. Griffiths (Eds.), Holocaust Education in Primary Schools in the Twenty-First Century - Current Practices, Potentials and Ways Forward, (pp.57-73). London: Palgrave Macmillan.

Eckmann, M. \& Stevick, E.D. (2017). General Conclusions, In M. Eckmann, E.D. Stevick \& J. Ambrosewicz- Jacobs (Eds.), Research in Teaching and Learning About the Holocaust: A Dialogue Beyond Borders, (pp. 285-300). Berlinp: Metropol.

Education Scotland (2018). National Improvement Framework and Improvement Plan For Scottish Education, Retrieved from http://hub.careinspectorate.com/media/623628/2018-nationalimprovement-framework-and-improvement-plan-for-scottish-education.pdf (Accessed 16/07/18).

Education Scotland (n.d.a) What is Curriculum for Excellence? Retrieved from https://education.gov.scot (Accessed 16/07/18).

Education Scotland (n.d.b) Engaging parents and families A toolkit for practitioners Section 3: Home/school/partnership settings. Retrieved from https://education.gov.scot (Accessed 16/07/18). 
Edwards, C., Gandini, I. \& Forman, G. (Eds.) (2011). The Hundred Languages of Children, Santa Barbara, C.A: Praeger Pub. Inc.

EIS (2017). Motions, Scottish Educational Journal, 101(4), 12.

EIS (2018). Briefing: Holocaust Education. Edinburgh: ElS. https://www.eis.org.uk/AntiRacism/BriefingHolocaustEducation (Accessed 05/12/18).

Flyvbjerg, B. (2006). Five Misunderstandings About Case-Study Research, Qualitative Inquiry, 12(2), 219-245.

Gallagher, S. (2014). An Education in Narratives. Educational Philosophy and Theory, 46(6), 600-609.

General Teaching Council for Scotland (GTCS) (2017). "It was like a killing factory", Teaching Scotland, 71, pp.32-34.

Gilbert, J., Hipkins, R. \& Cooper, G. (2005 May-June). Faction or fiction: Using narrative pedagogy in school science education. New Zealand Council for Educational Research. Paper presented at the Redesigning Pedagogy: Research, Policy, Practice conference, Nanyang University Institute of Education, Singapore.

Gillham, B. (2000). Case study research methods. London :Continuum.

Goodson, I.F. (2013). Developing Narrative Theory: Life histories and personal representation. Oxon \& New York: Routledge.

Harbaugh, C.L. (2015). Informed Pedagogy of the Holocaust: A Survey of Teachers Trained, by Leading Holocaust Organisations in the United States, In Z. Gross \& E.D. Stevick (Eds.), As the Witnesses Fall Silent: 21st Century Holocaust Education in Curriculum, Policy and Practice, (pp.375390). London: Springer.

Heddebaut, M. (2017). Enseigner là Shoah a l'école primaire [Teaching the Holocaust in the Primary School] (pp.47-58). Tsafon, 73.

Holocaust Educational Trust (HET), (2016). A Guide for Primary School Teachers, HET, London, available to registrants.

Huber, J., Caine, V., Huber, M. \& Steeves, P. (2013). 'Narrative Inquiry as Pedagogy in Education: The Extraordinary Potential of Living, Telling, Retelling, and Reliving Stories of Experience', Review of Research in Education, 37, 212-242.

Humes, W. (2013). Curriculum for Excellence and Interdisciplinary learning, Scottish Educational Review, 45(1), 82-93.

John, M. (2003). Children's rights and power: charging up for a new century, London: Jessica Kingsley.

Kinney, L. \& Wharton, P. (2007). An Encounter with Reggio Emilia: Children's Early Learning Made Visible. London: Routledge.

Kolirin, L. (2011, July 20). "Mummy, what was the Holocaust?" Jewish Chronicle, Retrieved from https://www.thejc.com.

Levine, K. (2003). Hana's Suitcase, London: Evans Brothers. 
LTS (Learning and Teaching Scotland) n.d. Curriculum for Excellence: Social Studies, Experiences and Outcomes, Retrieved from https://education.gov.scot/scottish-education-system/policy-for-scottisheducation/policy-drivers/cfe-(building-from-the-statement-appendix-incl-btc1-

5)/Experiences\%20and\%20outcomes\#soc (Accessed 05/12/18)

Maitles, H. \& Cowan, P. (1999). Teaching the Holocaust in Primary Schools in Scotland: modes, methodology and content, Educational Review, 51(3), 263-271.

Memorial de la Shoah (n.d.). Pedagogical Notes: Primary School, Retrieved from http://www.memorialdelashoah.org (Accessed 20/08/2018).

Menter, I., Elliot, D., Hulme, M., Lewin, J. \& Lowden, K., (2011). A Guide to Practitioner Research in Education. London: Sage.

Menter, I. \& Hulme, M. (2013) Developing the Teacher- or not?, In M. Priestley \& G. Biesta (Eds.), Reinventing the Curriculum, (pp.164-186).London: Bloomsbury.

Mintz, A.I. (2013). Helping by hurting: the paradox of suffering in social justice education. Theory and Research in Education, 11(3), 215-230.

Peaceman, H.D. (2003). Teaching the Holocaust in the USA: A German perspective, Intercultural Education, 14(2), 215-224.

Pietkiewicz, I. \& Smith, J.A. (2012). Praktyczny przewodnik interpretacyjnej analizy fenomenologicznej w badaniach jakościowych w psychologii. [A Practical Guide to Using Interpretative Phenomenological Analysis in Qualitative Research Psychology], Czasopismo Psychologiczne, [Psychological Journal], 18(2), 361-369.

Rak, J. (2003). Do Witness: Don't: A Woman's Word and Trauma as Pedagogy. Topia 10, 53-71.

Robertson, L., Hepburn, L., McLauchlan, A. \& Walker, J. (2017). The humanities in the primary school - where are we and in which direction should we be heading? A perspective from Scotland, Education 3-13, 45(3), 320-331.

Robinson, K. (Ed.) (1989). The Arts in Schools, London: Calouste Gulbenkian Foundation.

Saarni C. (2011) Emotional Development in Childhood. In: Tremblay RE, Boivin M, Peters RDeV, eds. Lewis M, topic ed. Encyclopedia on Early Childhood Development [online]. Retrieved from http://www.child-encyclopedia.com/emotions/according-experts/emotional-developmentchildhood. (Accessed 22/04/18).

Schiller, W. \& Einarsdottir, J. (2009). Special Issue: Listening to young children's voices in research-changing perspectives/changing relationships. Early Child Development and Care, 179(2), $125-130$.

Schostak, J. (2005). Interviewing and Representation in Qualitative Research. London: McGraw-Hill.

Schweber, S. (2008). "What happened to Their Pets?": Third Graders Encounter The Holocaust, Teachers College Record, 110(10), 2073-2115.Scottish Executive (2004). A Curriculum for Excellence: The Curriculum Review Group. Edinburgh: Scottish Executive.

Scottish Government (2005), Parents' Views on Improving Parental Involvement in Children's Education. Retrieved from http://www.gov.scot (Accessed 15/07/18). 
Scottish Schools (Parental Involvement) Act (2006). Retrieved from http://www.legislation.gov.uk (Accessed 29/08/18).

Shawn, K. (1999). What should they read, and when should they read it? A selective review of Holocaust literature for students in grades 2 through 6. In J.P. Robertson (Ed.) Teaching for a Tolerant World, (p. 424 ). Urbana, Illinois: National Council of Teachers in English.

Short, G. (2003). Lessons of the Holocaust: A response to the critics, Educational Review, 55(3), 277287.

Short, G. \& C.A. Reed (2004). Issues in Holocaust Education, Aldershot: Ashgate.

Smith, J., Flowers, P. \& Larkin, M. (2010). Interpretive Phenomenological Analysis: theory, method and research. Los Angeles, London: Sage.

Smith, J.A. \& Osborn, M. (2007). Interpretive Phenomenological Analysis. In J. A. Smith, (Ed.) Qualitative Psychology: A practical guide to research methods, (pp.53-80) London: Sage.

Stevick, E.D. \& Gross. Z. (2014). Research in Holocaust Education: emerging themes and directions, In K. Fracapane \& M. Haß (Eds.), Holocaust Education in a Global Context, (pp. 59-76). Paris: UNESCO.

Swanson, D. \& Williams, J. (2014). Making abstract mathematics concrete in and out of school. Educational Study of Mathematics, 86, 193-209.

Thorburn. M. (2017). Dewey, democracy and interdisciplinary learning: a Scottish perspective, Oxford Review of Education, 43(2), 242-254.

Totten, S. (1999). Should there be Holocaust education for K-4 students? The Answer is No, Social Studies and The Young Learner, 12(1), 36-39.

UNESCO (2011). 'We teach 40,000 children a year about the Holocaust', Retrieved from http://www.unesco.org (Accessed 24/03/18).

UNESCO Education (2014 January). The Impact of Holocaust Education: How to assess policies and practices. International Seminar, Paris: UNESCO.

Vygotsky, L. (1994). The development of thinking and concept formation in adolescence. In Vander Veer, R. \& Valsiner, J. (Eds.), The Vygtosky Reader (pp.185-265), Oxford: Basil Blackwell (Original Work published 1931/34).

Vygotsky, L. (1994). The development of academic concepts in school aged children. In Vander Veer, R. \& Valsiner, J. (Eds.), The Vygtosky Reader (pp.355-370), Oxford: Basil Blackwell: (Original Work published 1934/35).

Wells, G. (1994). Learning and Teaching "Scientific Concepts": Vygotsky's ideas revisited. Paper presented at the Conference "Vygotsky and the Human Sciences," Moscow, Sept. 1994.

Whiting, L. S. (2008). Semi-structured interviews: guidance for novice researchers. Nursing Standard, 22-23, 35.

Woodside, A. (2016). Case Study Research: Core Skills in using 15 genres. Bingley, Emerald Group Publishing Ltd.

Woolley, R. (2010). Tackling Controversial Issues in the Primary School: Facing Life's Challenges with Your Learners, London: Routledge. 
Zembylas, M. (2015). 'Pedagogy of discomfort' and its ethical implications: the tensions of ethical violence in social justice education, Ethics and Education, 10(2), 163-174.

Zembylas, M. \& McGlynn, C. (2012). Discomforting pedagogies: emotional tensions, ethical dilemmas and transformative possibilities, British Educational Research Journal, 38(1), 41-59.

Ziv, Y., Golden, D. \& Goldberg, T. (2015).Teaching Traumatic History to Young Children: The Case of Holocaust Studies in Israeli Kindergartens, Early Education and Development, 26, 520-533. 